\title{
Assessment of two medicinal plants, Psidium guajava L. and Achillea millefolium L., in in vitro and in vivo assays
}

\author{
Rosangela de Oliveira Teixeira ${ }^{1}$, Marjori Leiva Camparoto ${ }^{1}$, Mário Sérgio Mantovani ${ }^{2}$ \\ and Veronica Elisa Pimenta Vicentini ${ }^{1}$ \\ ${ }^{1}$ Universidade Estadual de Maringá, Departamento de Biologia Celular e Genética, Maringá, PR, Brazil. \\ ${ }^{2}$ Universidade Estadual de Londrina, Departamento de Biologia Geral, Londrina, PR, Brazil.
}

\begin{abstract}
The use of medicinal plants by the general population is an old and still widespread practice, which makes studies of their genotoxicity essential. Psidium guajava L. and Achillea millefolium L. are examples of plants commonly used in popular medicine. P. guajava L. is indicated for diarrhea and also as an antiseptic, while $A$. millefolium L. is indicated as an analgesic, antispasmodic, digestive, diuretic, antiseptic, astringent, emollient, wound healer and hemorrhoid medication. The aim of this study was to determine the effects of the infusions of these two plant species on chromosomes and the cell cycle. Leaves from the plants were used to prepare infusions, in the same manner as teas, but at two different concentrations. Allium cepa L. root-tip cells ( $P$. guajava L. -2.62 and $26.2 \mathrm{mg} / \mathrm{mL}$, and $A$. millefolium L. - 3.5 and $35.0 \mathrm{mg} / \mathrm{mL}$ ) and Wistar rat bone marrow cells (P. guajava L. -2.62 and $26.2 \mathrm{mg} / 100 \mathrm{~g}$ body weight, and $A$. millefolium L. - 3.5 and $35.0 \mathrm{mg} / 100 \mathrm{~g}$ body weight) were used as in vivo plant and animal test systems, respectively. Human peripheral blood lymphocytes ( $P$. guajava L. - 0.262 and $2.62 \mu \mathrm{g} / \mathrm{mL}$ culture medium, and $A$. millefolium L. -0.35 and $3.5 \mu \mathrm{g} / \mathrm{mL}$ culture medium) were used as in vitro test system. The $P$. guajava $\mathrm{L}$. infusion at the higher concentration caused a statistically significant inhibition of cellular division in the onion root-tip cells, not observed in onion root-tip cells treated with $A$. millefolium $\mathrm{L}$. No statistically significant alterations were found, as compared to untreated controls, in either the cell cycle or the number of chromosome alterations, after treatments with either plant, in rat cells or in cultured human lymphocytes. These results regarding the cytotoxicity and mutagenicity of these plants provide valuable information about the safety of using them as therapeutic agents.
\end{abstract}

Keywords: medicinal herbs, chromosome damage, mutagenicity test.

Received: November 29, 2002; Accepted: June 12, 2003.

\section{Introduction}

The medicinal use of plants is probably as old as Human kind itself. More than 150,000 plant species have been studied, and many of them contain therapeutic substances (Ishii et al., 1984; Hoyos et al., 1992). These substances can be extracted and used in the preparation of drugs, or the plant itself can be used directly as a medication, a practice that is particularly popular in developing countries. However, medicinal plants, and indeed plants in general, synthesize toxic substances, which in nature act as a defense against infections, insects and herbivores, but which often affect the organisms that feed on them. Thus, an assessment of their cytotoxic and mutagenic potential is necessary to ensure a relatively safe use of medicinal plants.

Send correspondence to Mário Sérgio Mantovani. Universidade Estadual de Londrina, Campus Universitário, Departamento de Biologia Geral (CCB), Caixa. Postal 6001, 86051-990 Londrina, PR, Brazil. E-mail: biomsm@uel.br.
The species Psidium guajava L. and Achillea millefolium L. are examples of plants commonly used in popular medicine. P. guajava L. belongs to the Myrtaceae family and is a twisted trunk. It has green leaves and white flowers. It contains essential oils, rutin, tannins, flavonoids, sesquiterpenic alcohol and triterpenoid acids. Tea made from its leaves or buds is indicated for diarrhea and also as an antiseptic. A. millefolium L. belongs to the Asteraceae family and contains aquileic acid, essential oils, tannins, flavonoids and acids. The infusion made from its leaves is indicated as an analgesic, antispasmodic, digestive, diuretic, antiseptic, astringent, emollient, and healing agent, as well as for hemorrhoid treatment (Silva et al., 1995).

In this study, infusions from the leaves of these two plant species, prepared at two different concentrations, were tested for acute mutagenicity in vivo in meristematic cells of Allium cepa L. root tips and Wistar rat bone marrow cells, and in vitro in lymphocytes from human peripheral blood. 


\section{Material and Methods}

\section{Infusions}

Psidium guajava L. and Achillea millefolium L. plants were obtained from the "Irenice Silva" medicinal plant garden of the Maringá State University. The infusions were prepared in the same way as they are usually made, in the quantities indicated below. Fresh Psidium guajava L. leaves were placed in a receptacle, covered with boiling water, and left to stand for 10 to $15 \mathrm{~min}$. The infusion was then strained and allowed to cool. The same procedure was carried out for Achillea millefolium L. Test solutions of the two plants were prepared at two different concentrations, one like the normally used in teas by the population, and the other ten times more concentrated. The infusions were utilized directly for experiments with Allium cepa L. root-tip cells, $1 \mathrm{~mL}$ of the infusion per $100 \mathrm{~g}$ body weight was administered in the experiments with Wistar rat bone marrow cells, and $0.1 \mathrm{~mL}$ of infusion per $10 \mathrm{~mL}$ culture medium was utilized in the tests with human lymphocytes. The following final concentrations were used for the treatment of onions: Psidium guajava L. - 2.62 and $26.2 \mathrm{mg} / \mathrm{mL}$, and Achillea millefolium L. -3.5 and $35.0 \mathrm{mg} / \mathrm{mL}$; for rats: Psidium guajava L. - 2.62 and $26.2 \mathrm{mg} / 100 \mathrm{~g}$, and Achillea millefolium L. - 3.5 and $35.0 \mathrm{mg} / 100 \mathrm{~g}$ body weight; and for lymphocytes: Psidium guajava L. - 0.262 and $2.62 \mu \mathrm{g} / \mathrm{mL}$, and Achillea millefolium L. - 0.35 and $3.5 \mu \mathrm{g} / \mathrm{mL}$ culture medium.

\section{Allium cepa L. root-tip cells}

Onions were placed in flasks with aerated water at room temperature to root. The control group was considered as time zero $(0 \mathrm{~h})$ until the first root sample was obtained, which served as control for the bulb. This root sample was then placed for $24 \mathrm{~h}$ in the treatment solutions, consisting of two concentrations for each of the two plants, while a control group was left in water for the same $24 \mathrm{~h}$. After this time period, a few more roots were removed, and the bulbs were returned to the water, for a further $24 \mathrm{~h}$, to observe if there was recovery from possible damage. The roots were fixed and stained by the Feulgen reaction and mounted on permanent slides.

The slides were analyzed in a blind test, using an optical microscope with $40 \mathrm{X}$ objective lens. A thousand cells per bulb were analyzed, totaling 6,000 for control, treatment, and respective recovery. Cells were examined for morphological and structural alterations, and the mitotic index (MI) was determined.

\section{Wistar rat bone marrow cells}

Wistar rats, Rattus norvegicus, weighing approximately $100 \mathrm{~g}$ b.w. were obtained from the Central Animal House of the Maringá State University. Six animals were used, three males and three females, for each control and treatment group.
The rats were treated in vivo by intraperitoneal injection with $1 \mathrm{~mL} / 100 \mathrm{~g}$ b.w. of the treatment solutions, prepared at the two concentrations described for each of the two plants. The positive control animals were treated with $1.5 \mathrm{mg} / 100 \mathrm{~g}$ b.w. cyclophosphamide (CP). The animals were sacrificed $24 \mathrm{~h}$ later, with colchicine $(0.16 \%)$ injected intraperitoneally $(0.5 \mathrm{~mL} / 100 \mathrm{~g}$ b.wt. $)$ an hour and a half previously. Bone marrow cells were obtained from the rats using the technique described by Ford and Hamerton (1956) and Preston et al. (1981; 1987a). Cytogenetic analysis of the slides was performed with a light microscope using a 100x oil immersion lens. One hundred metaphases were analyzed per animal in a blind test, making up a total of 600 metaphases per control and treatment group. The MI was calculated for 5,000 cells per sex, totaling 10,000 cells per group.

\section{Human lymphocytes}

Human peripheral blood lymphocytes were used to prepare cultures for in vitro testing. Lymphocytes were obtained from five healthy, male and female individuals, about 20 years of age, apparently free from infection by pathogenic agents, and who had not been under any treatment for the last six months. The cells were incubated for 8 $\mathrm{h}$ in $10 \mathrm{~mL}$ of culture medium consisting of $80 \% \mathrm{RPMI}$ 1640 medium (4\% phytohemagglutinin) and $20 \%$ fetal calf serum, at $37^{\circ} \mathrm{C}$. The cultures were then treated with $0.1 \mathrm{~mL}$ of the test infusions, prepared at the two concentrations for each of the two plants. The positive controls were treated with $0.03 \mu \mathrm{g} / \mathrm{mL}$ mitomycin-C. Cultures were incubated for another $64 \mathrm{~h}$ and harvested. To each culture $0.05 \mathrm{~mL}$ of colchicine solution $(0.016 \mathrm{mg} / \mathrm{mL})$ were added $105 \mathrm{~min}$ before fixation.

Macrocultures of peripheral human blood lymphocytes were prepared according to Moorhead et al. (1960) and Preston et al. (1981, 1987b), and used to determine the frequency and distribution of chromosome alterations. One hundred metaphases were analyzed in a blind test from each control and treatment culture, from the five individuals assessed, totaling 500 cells per group. Two thousand cells were calculated for the MI, totaling 10,000 cells per group.

\section{Statistical analysis}

The data were statistically analyzed by the conditional test for the detection of rare events (Pereira, 1991), with the level of significance set at $\alpha=0.05$.

\section{Results}

\section{Allium cepa L. root-tip cells}

Table 1 shows the results obtained with the infusion of Psidium guajava L.: the total mean MI, the total number of analyzed cells, and the number of cells in each one of the different phases of the cell cycle (interphase, prophase, 
Table 1 - Treatment of Allium cepa L. root-tip cells with two different concentrations of Psidium guajava L. (Pg).

\begin{tabular}{|c|c|c|c|c|c|c|c|c|}
\hline \multirow{2}{*}{$\begin{array}{l}\text { Treatment } \\
(\mathrm{mg} / \mathrm{mL})\end{array}$} & \multirow[t]{2}{*}{ Group } & \multirow{2}{*}{$\begin{array}{l}\text { Cell } \\
\text { total }\end{array}$} & \multirow{2}{*}{$\begin{array}{c}\text { MI }(\%) \\
\text { mean }\end{array}$} & \multicolumn{5}{|c|}{ Number of cells } \\
\hline & & & & I & $\mathrm{P}$ & M & $\mathrm{A}$ & $\mathrm{T}$ \\
\hline \multirow{3}{*}{ Control } & Co & 6000 & 8.4 & 5497 & 236 & 104 & 95 & 68 \\
\hline & $\operatorname{Tr}$ & 6000 & 7.8 & 5528 & 176 & 134 & 95 & 67 \\
\hline & $\operatorname{Re}$ & 6000 & 7.8 & 5532 & 253 & 104 & 71 & 40 \\
\hline \multirow{3}{*}{$P g(2.62)$} & Co & 6000 & 9.7 & 5417 & 341 & 120 & 99 & 23 \\
\hline & $\operatorname{Tr}$ & 6000 & 6.1 & 5635 & 181 & 92 & 68 & 24 \\
\hline & $\operatorname{Re}$ & 6000 & 5.6 & 5665 & 140 & 98 & 62 & 35 \\
\hline \multirow{3}{*}{$\operatorname{Pg}(26.2)$} & Co & 6000 & 7.6 & 5539 & 272 & 84 & 60 & 45 \\
\hline & $\operatorname{Tr}$ & 6000 & $1.1^{*}$ & 5937 & 24 & 28 & 7 & 4 \\
\hline & $\mathrm{Re}$ & 6000 & 5.3 & 5681 & 176 & 70 & 50 & 23 \\
\hline
\end{tabular}

I: Interphase; P: Prophase; M: Metaphase; A: Anaphase; and T: Telophase. Co - Control-0 h; Tr - Treatment-24 h; and Re - Recovery-24 h. *Statistically significant.

metaphase, anaphase and telophase), for each group of six onions, the controls and the treated plants. Table 2 shows the results obtained with Achillea millefolium L. plants, for the two concentrations and the recovery.

Only the treatment with Psidium guajava L. infusion at the higher concentration gave a result showing a statistically significant difference as compared to the control. Similar data were found when the results obtained with this treatment were compared with the recovery results, indicating that there was a recovery of cell division after $24 \mathrm{~h}$ in water. Achillea millefolium L. infusion did not produce any statistically significant difference when the results from the treatments were compared with the results of the control and the respective recovery.

Thus, infusions of Psidium guajava L. at the lower concentration and of Achillea millefolium L. at either concentration did not cause significant suppression of cell division in the Allium cepa L. root-tip cells, within the 24-h treatment period. There was a strong, statistically signifi- cant inhibition of cell division with the higher concentration of Psidium guajava L. infusion. However, this antimitotic effect cannot have been too drastic, as cell growth recovered after $24 \mathrm{~h}$ in water.

\section{Wistar rat bone marrow cells}

Table 3 shows the results obtained in male and female Wistar rats treated with infusions of Psidium guajava $\mathrm{L}$. and Achillea millefolium L., at both concentrations: the total mean MI, the total of analyzed metaphases, and the number and types of chromosome alterations, for untreated controls and treated animals.

Infusions of Psidium guajava L. or Achillea millefolium L., at either of the two concentrations, did not induce a statistically significant increase in the number of chromosome alterations, nor did they alter cell division rates in Wistar rat bone marrow cells, as compared to the results obtained from untreated controls.

Table 2 - Treatment of Allium cepa L. root-tip cells with two concentrations of Achillea millefolium L. (Am).

\begin{tabular}{lcccccccc}
\hline \multirow{2}{*}{$\begin{array}{l}\text { Treatment } \\
(\mathrm{mg} / \mathrm{mL})\end{array}$} & Group & \multirow{2}{*}{$\begin{array}{c}\text { Cell } \\
\text { total }\end{array}$} & $\begin{array}{c}\text { MI }(\%) \\
\text { mean }\end{array}$ & & \multicolumn{7}{c}{ Number of cells } \\
\cline { 6 - 9 } Control & & & & $\mathrm{I}$ & $\mathrm{P}$ & $\mathrm{M}$ & $\mathrm{A}$ & $\mathrm{T}$ \\
& $\mathrm{Co}$ & 6000 & 4.4 & 5736 & 155 & 50 & 27 & 32 \\
& $\mathrm{Tr}$ & 6000 & 3.0 & 5820 & 109 & 43 & 13 & 15 \\
& $\mathrm{Re}$ & 6000 & 3.5 & 5791 & 109 & 67 & 17 & 16 \\
\hline \multirow{3}{*}{$A m(3.5)$} & $\mathrm{Co}$ & 6000 & 3.7 & 5777 & 100 & 48 & 35 & 40 \\
& $\mathrm{Tr}$ & 6000 & 2.0 & 5880 & 57 & 36 & 14 & 13 \\
& $\mathrm{Re}$ & 6000 & 2.3 & 5862 & 82 & 33 & 12 & 11 \\
\hline \multirow{3}{*}{$A m(35.0)$} & $\mathrm{Co}$ & 6000 & 4.2 & 5746 & 130 & 51 & 43 & 30 \\
& $\mathrm{Tr}$ & 6000 & $1.2^{*}$ & 5927 & 47 & 16 & 9 & 1 \\
& $\mathrm{Re}$ & 6000 & 3.2 & 5807 & 109 & 45 & 21 & 108 \\
\hline
\end{tabular}

I: Interphase; P: Prophase; M: Metaphase; A: Anaphase; and T: Telophase. Co - Control-0h; Tr - Treatment-24 h; and Re - Recovery-24 h. *Statistically significant. 
Table 3 - Types of cytogenetic alterations in bone marrow cells of Wistar rats treated with two concentrations of Psidium guajava L. (Pg) and Achillea millefolium L. (Am).

\begin{tabular}{|c|c|c|c|c|c|c|c|}
\hline \multirow{3}{*}{$\begin{array}{l}\text { Treatment } \\
\text { (mg/100 g b.w.) }\end{array}$} & \multirow{3}{*}{$\begin{array}{c}\mathrm{IM}(\%) \\
\text { mean total }\end{array}$} & \multirow{3}{*}{$\begin{array}{l}\text { Alteration } \\
\text { total }(\%)\end{array}$} & \multicolumn{4}{|c|}{ Alteration } & \multirow{3}{*}{$\begin{array}{l}\text { Metaphase } \\
\text { total }\end{array}$} \\
\hline & & & \multicolumn{2}{|c|}{ Gap } & \multicolumn{2}{|c|}{ Break } & \\
\hline & & & $\mathrm{ct}$ & $\mathrm{cr}$ & ct & $\mathrm{cr}$ & \\
\hline Control & 1.32 & $2(0.3)$ & 0 & 1 & 1 & 0 & 600 \\
\hline $\mathrm{CP}$ & 1.32 & $79(13.2)^{*}$ & 6 & 0 & 46 & 27 & 600 \\
\hline$P g(2.62)$ & 1.86 & 0 & 0 & 0 & 0 & 0 & 600 \\
\hline$P g(26.2)$ & 1.99 & 0 & 0 & 0 & 0 & 0 & 600 \\
\hline$A m(3.5)$ & 0.90 & $4(0.7)$ & 2 & 0 & 1 & 1 & 600 \\
\hline$A m(35.0)$ & 1.40 & $3(0.5)$ & 0 & 0 & 2 & 1 & 600 \\
\hline
\end{tabular}

ct: chromatid; cr: chromosome. CP - $1.5 \mathrm{mg}$ cyclophosphamide/100g body weight (positive control). *Statistically significant.

\section{Human lymphocytes}

Table 4 shows the results obtained with infusions of Psidium guajava L. and Achillea millefolium L., at the two concentrations, in human lymphocytes from five individuals, three males and two females: mean total MI values, total of metaphases analyzed, and types and numbers of alterations found in treated cells and in untreated controls.

The infusions of the two plants, at the concentrations studied and within the treatment period used, did not show mutagenic effects nor growth inhibitory effects, as compared to untreated controls. The infusions did not induce chromatid or chromosome breaks or gaps, nor did they significantly increase the incidence of these alterations.

\section{Discussion}

The data obtained in these experiments, two in vivo treatments including one animal test system and one in vitro treatment with a mammalian cell test system, indicate that the infusions of the Psidium guajava L. and Achillea millefolium L. plants, at the concentrations tested and used as described above, do not have mutagenic effects on metaphase chromosomes and do not affect cell division. In spite of the strong inhibition of cell division caused by the higher concentration of both the Psidium guajava L. and the Achillea millefolium L. infusions in the Allium cepa $\mathrm{L}$. root meristem test system, this antiproliferative effect was rather cytostatic than cytotoxic, since there was recovery of cell division after replacement of the plant infusion by water for $24 \mathrm{~h}$.

In this study, the effects of Psidium guajava L. and Achillea millefolium $\mathrm{L}$. infusions were assessed in three test systems, one plant, one rodent and one human, taking into account that any particular substance may produce different results in different test systems. However, most of the negative results were coincident in the three systems tested. There was also a concern to test extracts prepared in the same way and at the same concentrations as the therapeutic teas used by the population at large, so as to assess the effects of the medicinal plants in the form they are actually administered. Thus, the commonly used concentration was tested and another one, ten times stronger, to assess whether this higher concentration had any toxic or mutagenic effects. An antimitotic effect was only observed with the higher concentration of both Psidium guajava L. and Achillea millefolium L. in Allium cepa L., and this effect was not irreversible, as cell division recovered within $24 \mathrm{~h}$.

Table 4 - Types of cytogenetic alterations in human lymphocytes treated with two concentrations of Psidium guajava L. (Pg) and Achillea millefolium L. $(\mathrm{Am})$.

\begin{tabular}{|c|c|c|c|c|c|c|c|}
\hline \multirow{3}{*}{$\begin{array}{l}\text { Treatment } \\
(\mu \mathrm{g} / \mathrm{mL} \text { culture } \\
\text { medium })\end{array}$} & \multirow{3}{*}{$\begin{array}{c}\mathrm{IM}(\%) \\
\text { mean total }\end{array}$} & \multirow{3}{*}{$\begin{array}{c}\text { Alteration } \\
\text { total }(\%)\end{array}$} & \multicolumn{4}{|c|}{ Alteration } & \multirow{3}{*}{$\begin{array}{c}\text { Metaphase } \\
\text { total }\end{array}$} \\
\hline & & & \multicolumn{2}{|c|}{ Gap } & \multicolumn{2}{|c|}{ Break } & \\
\hline & & & ct & $\mathrm{cr}$ & ct & $\mathrm{cr}$ & \\
\hline Control & 2.54 & 0 & 0 & 0 & 0 & 0 & 500 \\
\hline MMC & 2.33 & $72(14.4)^{*}$ & 6 & 0 & 40 & 26 & 500 \\
\hline$P g(0.262)$ & 2.63 & 0 & 0 & 0 & 0 & 0 & 500 \\
\hline$P g(2.62)$ & 2.26 & $1(0.2)$ & 0 & 0 & 1 & 0 & 500 \\
\hline$A m(0.35)$ & 2.24 & $1(0.2)$ & 0 & 0 & 1 & 0 & 500 \\
\hline$A m(3.5)$ & 2.43 & $2(0.4)$ & 1 & 0 & 1 & 0 & 500 \\
\hline
\end{tabular}

ct: chromatid; cr: chromosome. MMC: mitomycin-C $0.03 \mu \mathrm{g} / \mathrm{mL}$ (positive control). *Statistically significant. 
The Psidium guajava L. and Achillea millefolium L. plants contain tannins, complex chemical substances which are distributed throughout the plants. These tannins protect plants against herbivores and the action of nitrogen-fixing bacteria, besides inhibiting seed germination. They have the property of precipitating proteins, and are used for the tanning of leather and skins. At high doses, tannins can irritate the mucous tissues, and at low doses they can make them impermeable, as they precipitate small quantities of proteins. This can prevent the penetration of damaged mucous tissues by noxious agents, thereby explaining their anti-diarrheal and healing properties. In addition, they are good enzyme inhibitors and act as antidotes for certain types of alkaloids (Martins et al., 1995). Horikawa et al. (1994) evaluated the activity of six Chinese medicinal herbs against benzo $[a]$ pyrene and found that tannin compounds and catechins were responsible for the inhibition of mutagenicity in Salmonella.

The Psidium guajava L. and Achillea millefolium L. plants contain tannins, which, as effective enzyme inhibitors, may be the compounds in the infusion responsible for the inhibition of cell division in the Allium cepa L. root meristem. It is also known that the inhibitory effect of tannins requires continuous exposure of the cells or tissues in question to these substances. This could explain the recovery of cell division after discontinuation of the treatment and the returning of the roots to water for $24 \mathrm{~h}$, thus removing them from the continuous exposure to the tannincontaining test solutions.

Psidium guajava $\mathrm{L}$. also contains flavonoids, and, according to Bu-Abbas et al. (1996), the high concentration of these substances in green tea, as compared to black tea, may indicate that this component is among those responsible for the antimutagenic, and probably anticarcinogenic, properties attributed to green tea or its fermented products. Ohtsuka et al. (1995) examined the effects of nine active compounds of the Chinese medicinal herb sho-saiko-to on the mutagenic effect of AF-2, and found the main active groups to be saponins and flavonoids.

The presence of cetequinic components and flavonoids in Psidium guajava L. and of tannins found in both Psidium guajava L. and Achillea millefolium L. could account for the lack of mutagenic effects caused by infusions of these plants at the concentrations studied and in the test systems used here. These compounds have been shown by other investigators to possess antimutagenic effects in a different test system, a property that was not specifically addressed in the present study.

Thus, the results of the present study do not recommend the consumption of tea made of these plants. Should it however be consumed, it is recommended that the tea should be prepared exactly according to the recipe and taken in the prescribed doses, bearing in mind that its prolonged use is not advisable. A long period of rest is recommended between uses of the plants, to allow the person to recover or to lose the habit, so that the plant can act more effectively without being toxic. Therefore, caution regarding the indiscriminate use of medicinal plants by the population continues to be extremely necessary.

\section{Acknowledgments}

The authors thank Irenice Silva for her collaboration in the selection and identification of the plants.

\section{References}

Bu-Abbas A, Nunez X, Clifford MN, Walker R and Ioannides C (1996) A comparison of the antimutagenic potential of green, black and decaffeinated teas: contribution of flavanols to the antimutagenic effect. Mutagenesis 11:597-603.

Ford CE and Hamerton JL (1956) A colchicine, hypotonic citrate, squash sequence for mammalian chromosome. Stain Technology 31:247-251.

Horikawa K, Mohri T, Tanaka Y and Tokiwa H (1994) Moderate inhibition of mutagenicity and carcinogenicity of benzo[a]pyrene, 1,6-dinitropyrene and 3,9-dinitrofluoranthene by Chinese medicinal herbs. Mutagenesis 9:523-526.

Hoyos LS, Au WW, Heo MY, Morris DL and Legator MS (1992) Evaluation of the genotoxic effects of a folk medicine, Petiveria alliacea (anamu). Mutation Research 280:29-34.

Ishii R, Yoshikawa H, Minakata NT, Komura K and Kada T (1984) Specificity of bio-antimutagens in the plant kingdom. Agricultural and Biological Chemistry Journal 48:2587-2591.

Martins ER, Castro DM, Castellani DC and Dias JE (1995) Plantas Medicinais. Imprensa Universitária, Viçosa, MG, Brasil, pp 220.

Moorhead PS, Nowell PC, Mellman WJ, Battips DM and Hungerford DA (1960) Chromosome preparation of leukocytes cultured from human peripheral blood. Experimental Cell Research 20:613.

Ohtsuka M, Fukuda K, Yano H and Kojiro M (1995) Effects of nine active ingredients in Chinese herbal medicine sho-saiko-to on 2-(2-furyl)-3-(5-nitro-2-furyl) acrylamide mutagenicity. Japanese Journal of Cancer Research 86:1131-1135.

Pereira, CAB (1991) Teste estatístico para comparar proporções em problemas de citogenética. In: Rabello-Gay MN, Rodrigues MAR and Monteleone-Neto R (eds) Mutagênese, Teratogênese e Carcinogênese. Métodos e Critérios de Avaliação. Sociedade Brasileira de Genética, Ribeirão Preto, SP, pp 113-121.

Preston RJ, Au W, Bender MA, Brewen JG, Carrano AV, Heddle JA, Mcfee AF, Wolf S and Wassom JS (1981) Mammalian in vivo and in vitro cytogenetic assays: A report of the U.S.EPA`s Gene-Tox Program Mutat Res 87:143-188.

Preston RJ, Dean BJ, Galloway S, Holden H, Mcfee AF and Shelby M (1987a) Mammalian in vivo cytogenetic assays. Analysis of chromosome aberrations in bone marrow cells. Mutat Res 189:157-165.

Preston RJ, San Sebastian, JR and Macfee AF (1987b) The in vitro human lymphocyte assay for assessing the clastogenicity of chemical agents. Mutat Res 189:175-183.

Silva I, Franco SL, Molinari SL, Conegero CI, Miranda Neto MH, Cardoso MLC, Sant' ana DMG and Iwanko, NS (1995) Noções Sobre o Organismo Humano e Utilização de Plantas Medicinais. Assoeste - Editora Educativa, Cascavel, PR, Brasil, pp 203.

Editor: Catarina S. Takahashi 